\title{
DIFFUSE ARTERIOPATHY
}

\author{
BY \\ WILLIAM EVANS \\ From the Cardiac Department of the London Hospital
}

Received February 19, 1962

Arterial disease makes itself known through a diminished blood supply to a tissue or viscus as the result of narrowing or occlusion of the arterial lumen, or else it follows a break in the vessel wall. The symptoms arising from these effects vary with the particular territory nourished by the diseased artery.

In the case of intermittent claudication from atherosclerosis of the aorta or its branches to the lower extremities, the changes may be confined to these arterial units. Similarly, cardiac pain from coronary arterial disease is often a lone symptom, although it is not infrequently found in association with systemic hypertension, and the same is true of faulty vision from retinal arteriolar disease. In systemic hypertension, however, a wider arterial field may be deranged, so that in addition to involvement of the small renal arteries, the brachial arteries and retinal arterioles are contracted. The presence of renal and cerebral arterial disease, either in association with hypertension or when affected independently, may not yield as readily to clinical detection.

In the condition described here, for which the term Diffuse Arteriopathy is proposed, examination of a patient, in whom an isolated ischæmic effect has made itself known, unexpectedly discloses the presence of generalized arterial disease. An account of the syndrome is related in regard to its presentation in four patients.

Case 1. Consulting an ophthalmologist for a change of glasses which had been broken, a man of 52 years of age was found to have narrow retinal arterioles, several flame-shaped hæmorrhages, and many cotton-wool areas of exudation in both retinæ, although his vision was unimpaired. His blood pressure was only $185 / 110 \mathrm{~mm}$. $\mathrm{Hg}$, but the electrocardiogram showed left ventricular preponderance: the tracing also showed depression of the S-T segment in leads IIIR and CR4 from limited cardiac infarction, although he was not then subject to cardiac pain (Fig. 1A). The urine contained a trace of albumin. The brachial arteries were contracted. Two years later he experienced nocturnal breathlessness, when the blood pressure was found to be $160 / 120 \mathrm{~mm}$. $\mathrm{Hg}$, and the left ventricle a little enlarged, while pulmonary congestion was present at cardioscopy: treatment was given for his heart failure. Although the electrocardiographic signs of cardiac infarction had increased, cardiac pain was still absent, but the signs of left ventricular hypertrophy had also progressed (Fig. 1B). When the blood pressure had risen to $245 / 150 \mathrm{~mm}$. $\mathrm{Hg}$, the retinæ showed remarkable improvement and the areas of hæmorrhage had disappeared. A sudden loss of the use of his right leg was followed by recovery in the course of a day and without residual palsy. Hæmaturia occurred on one occasion. Slight albuminuria continued, but the blood urea was $29 \mathrm{mg} . / 100 \mathrm{ml}$. Three months later, cardiac pain set in. His blood pressure remained high, and values like $240 / 170 \mathrm{~mm}$. $\mathrm{Hg}$ were obtained; but in spite of this the retinæ continued to show no changes other than narrowing of the arterioles. The heart failure improved following treatment, but renal failure made its appearance, and the blood urea rose to $300 \mathrm{mg} . / 100 \mathrm{ml}$. before his demise.

Summary. The fortuitous finding of disease of the retinal arterioles in this patient led to the discovery of occlusive disease of other arterial units which included the coronary, renal, cerebral, and peripheral arteries. Thus, a routine electrocardiogram showed evidence of cardiac infarction before the onset of cardiac pain. Occlusive disease of the small renal arteries was made known 
through the development of systemic hypertension and ultimately renal failure ensued. The remarkable recession of retinopathy in the face of a progressive rise of blood pressure supported the opinion formed at the commencement of the illness that the retinal arterioles were affected primarily, and not secondarily, as a hypertensive effect, for they initiated symptoms before the blood pressure was significantly raised, although left ventricular preponderance was present in the electrocardiogram. A transient monoplegia told of cerebral arterial involvement.

Case 2. When a man of 57 years complained of chest pain the electrocardiogram confirmed the presence of cardiac infarction and it also showed the early changes of left ventricular preponderance (Fig. 2A). A month later he experienced faulty vision in the right eye when he was found to have extensive occlusive disease of the arterioles with multiple retinal hæmorrhages; blindness followed, but the left retina remained healthy except for a small hæmorrhage discovered at a single examination. The blood pressure at the time was $135 / 100 \mathrm{~mm}$. $\mathrm{Hg}$, but in the course of two years it rose to $180 / 130 \mathrm{~mm}$. $\mathrm{Hg}$ and the signs of left ventricular preponderance increased (Fig. 2B). Cardiac pain did not recur. On three occasions he became subject to episodes of hallucination and periods of disorientation; once he exhibited physical violence which lasted three days though at the time the blood pressure was natural. Later, although the blood pressure continued to rise showing values like $220 / 150 \mathrm{~mm}$. $\mathrm{Hg}$, no changes took place in the left retina apart from moderate narrowing of the arterioles, but the left ventricle began to enlarge as determined by cardioscopy, a test that disclosed pulmonary congestion and that coincided with the onset of cardiac asthma from left ventricular failure. The effects of left ventricular hypertrophy had again increased in the cardiogram, but those from cardiac infarction remained stationary (Fig. 2C). The brachial arteries were thickened and moderately contracted. Albumin appeared in the urine, and the blood urea rose to $72 \mathrm{mg} . / 100 \mathrm{ml}$. He deteriorated speedily with extended signs of heart and renal failure appearing before his death.

Summary. This patient presented evidence of generalized arterial disease involving the retinal arterioles, and the coronary, renal, and cerebral arteries. His illness started with cardiac pain from coronary arterial disease, and was followed soon after by the effects of severe occlusive disease of the retinal arterioles on one side and at a time when the blood pressure was normal. Later, renal arterial involvement made itself known through systemic hypertension, and renal and heart failure caused his demise.

Case 3. At the age of 55 years, this patient experienced weakness of his right hand when building a wall. He rested and fell asleep, but on waking he found his right leg had also become paralysed: his speech was not affected. Although he had noticed no visual disturbance, retinoscopy discovered gross changes, which included many areas of hæmorrhage and exudates as well as great narrowing of the arterioles. His blood pressure was $170 / 110 \mathrm{~mm}$. $\mathrm{Hg}$, and there was no enlargement of the left ventricle. The electrocardiogram was deformed primarily from the effects of coronary arterial disease, although he had never experienced cardiac pain, and also from signs of left ventricular preponderance (Fig. 3A). In spite of severe residual signs in the retinæ the vision remained unimpaired. When the blood pressure was $160 / 105 \mathrm{~mm}$. $\mathrm{Hg}$ his brachial arteries were noticeably thickened. He remains free from cardiac pain although extended changes from cardiac infarction are apparent in a cardiogram which also shows greater left ventricular preponderance (Fig. 3B). In concert with this last change, and a rise of blood pressure to $220 / 150 \mathrm{~mm}$. $\mathrm{Hg}$, has been the onset of left ventricular failure needing digitalization and the use of oral diuretics.

Summary. The presence of cerebral arterial disease in this patient was made known through the sudden onset of hemiplegia. Examination at the time showed disease in other arterial territories in the absence of symptoms. Thus, his retinæ showed gross changes from arteriolar occlusion although vision was unimpaired. His blood pressure was hardly raised, but evidence of left ventricular hypertrophy was discernible in the electrocardiogram which showed obvious signs of cardiac infarction and in the absence of cardiac pain. Later, clinical and cardiographic signs of systemic hypertension became more apparent, and when left ventricular failure ensued, the blood pressure had risen to $220 / 150 \mathrm{~mm}$. $\mathrm{Hg}$.

Case 4. Tiredness was the only complaint that brought this man of 48 years of age to see his doctor. Clinical examination found no abnormal signs, and his blood pressure was $140 / 100 \mathrm{~mm}$. $\mathrm{Hg}$, but the electrocardiogram showed signs of cardiac infarction, surprisingly for he complained of no chest pain, and it also disclosed signs of early left ventricular preponderance (Fig. 4A). Shortly afterwards, he experienced dimness of vision affecting the right eye when retinoscopy, not carried out at the previous examination, showed narrowing of the arterioles on both sides and multiple hæmorrhages on the right side. The urine 
contained albumin, and his brachial arteries were thickened and contracted. On occasion he suffered from episodes of unusual amnesia and disorientation. His blood pressure latterly has fluctuated, so that one time it might be $230 / 145$ and another time $150 / 105 \mathrm{~mm}$. $\mathrm{Hg}$, although evidence of left hypertrophy is still small in the cardiogram which now shows extended changes from cardiac infarction (Fig. 4B).

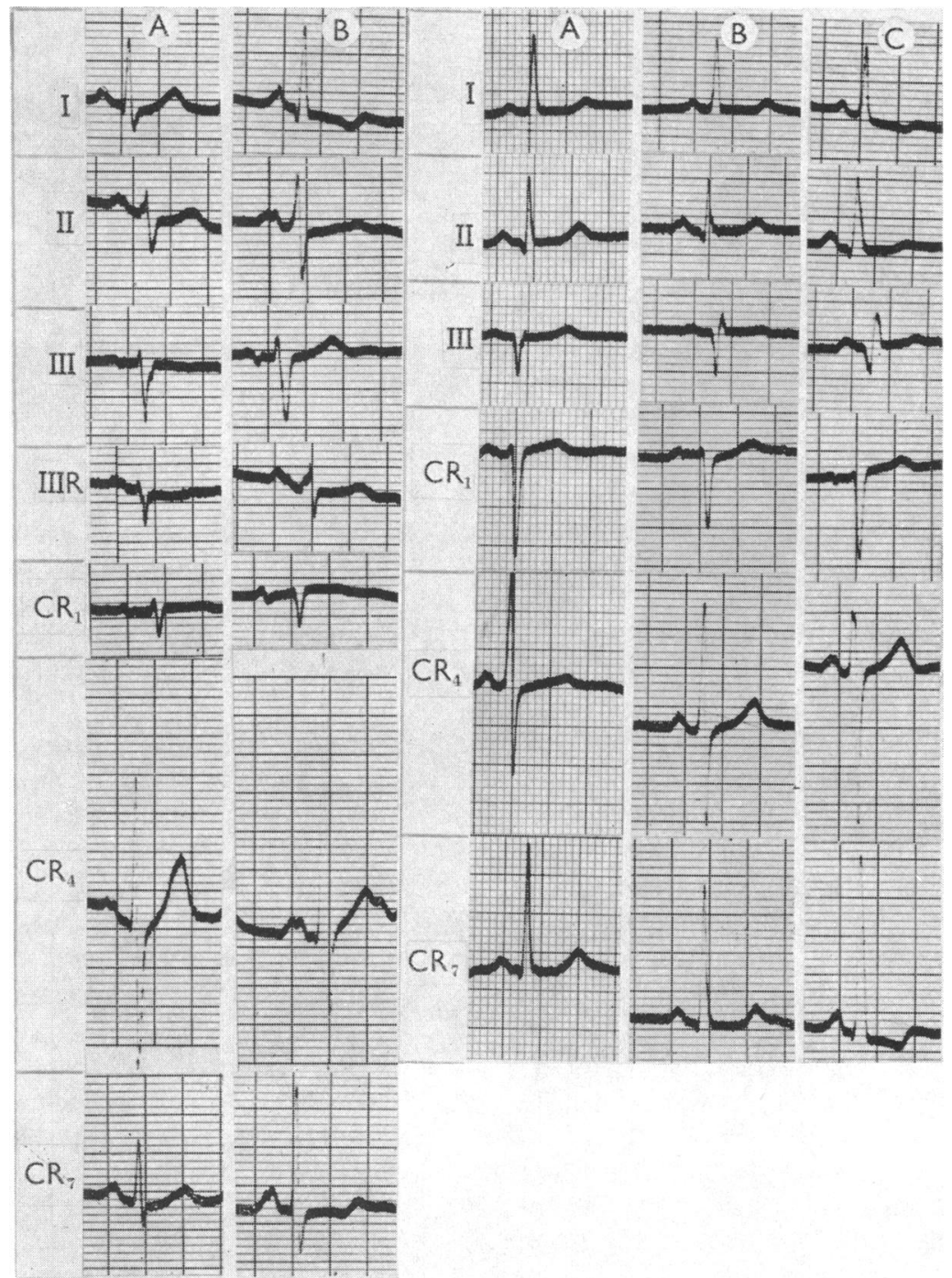

FIG. 1.-Cardiac infarction told by S-T depression in IIIR and CR4 in (A), and by added signs, especially a deep $S$ wave in leads II, III, and IIIR in the absence of an $S$ in lead I in (B) recorded two years later. $A$ low $T$ wave in leads I and CR7 together with left ventricular excitation, shown by a raised R1/RS4/ $R 7$ value of $56 \mathrm{~mm}$. in (A) and $73 \mathrm{~mm}$. in (B), provided evidence of left ventricular

FIG. 2.-Cardiac infarction told by S-T depression, greater in I than in CR7, and a very low $T$ wave in $C R 4$, in tracing (A). In (B) and (C), recorded at intervals of two and eight years respectively, these signs are obscured by those of left ventricular hypertrophy. Left ventricular excitation, absent in (A) is present in (B) and (C) with R1/ RS4/R7 values of 56 and $60 \mathrm{~mm}$. (from Case 2). hypertrophy (from Case 1). 
Summary. Disease of the retinal arterioles occasioned the initial symptom of faulty vision in the absence of systemic hypertension, and at the same time routine electrocardiography discovered frank cardiac infarction although without cardiac pain. Mental disturbances at intervals and significant rises of blood pressure on other occasions indicate derangement of his cerebral and probably of the renal arteries as well. A phæochromocytoma has been excluded.

\section{Plurality of Arterial Lesions}

The illness occasioned by diffuse arteriopathy develops insidiously and remains undetected until a complication affecting a single arterial unit breaks out to warrant a clinical examination which discovers widespread disease in other arterial territories. The mode of its presentation depends on the location of the occluded or ruptured vessel, whether involving the retinal, cerebral, coronary, renal, or limb circulation.

The symptoms arising from such arteriopathy occur singly or may be multiple depending on its distribution. It is in the latter circumstance that uncertainty exists concerning the mechanism underlying the illness, whether involvement of more than one arterial unit has resulted from the spread of arterial disease, or whether the presence of one abnormal state like hypertension can cause another like cardiac infarction. At the onset, however, there is need to realize that should symptoms arise from arterial disease affecting separate systems, in addition to a consideration as to which condition initiated the other, must come the appreciation that both may be common entities liable to visit a patient during the same age-span, so that they are to be regarded as associated lesions and not explained as cause and effect.

The subject is now to be examined in relation to the symptoms (Table I) appearing in the four examples of diffuse arteriopathy reported here, and in the larger series of patients from which these four cases were drawn.

Retinal Arteriolar Occlusion. In 2 of the 4 patients, hæmorrhages and exudates were discovered in both retinæ on routine clinical examination, and the same changes were confined to one side in the other 2, examined on account of sudden dimness of vision. At the time, the blood pressure was $140 / 100$ or less in two and $185 / 110 \mathrm{~mm}$. Hg or less in the other two. In all four the retinal lesions subsided except for arteriolar contraction during a time when the blood pressure continued to rise.

When the retinal changes were florid, the electrocardiogram confirmed the presence of coronary arterial disease in each, and there was evidence of cerebral derangement in 2, while the presence of renal arterial involvement, as instanced by the subsequent development of systemic hypertension, was confirmed in each patient.

In 100 patients with systemic hypertension examined consecutively, who had a mean blood pressure of $230 / 130 \mathrm{~mm}$. Hg, retinoscopy discovered narrowing of the arterioles in 55, which in 4 was associated with papillodema, and in 3 with hæmorrhages and exudates. In these 7 patients, dimness of vision was the uppermost symptom in 2, a second symptom in 1, and was absent in the remaining 4. Most ophthalmologists agree that the retinal arterioles in hypertension show thickening of their walls and narrowing of the lumen, changes that were present in each of 16 patients examined clinically, and by histology at necropsy, by Greear (1940). These changes appear to affect the arterioles of the choroid to a greater extent than the retinæ. Although it is usual to assume that both hæmorrhagic and exudative areas are ischæmic effects resulting from occlusion of the arterioles, doubt has been cast on the invariable truth of this by Manlove (1946) who found the changes in the absence of arteriolar disease apart from a little medial thickening. To dispute the presence of localized occlusive disease, however, in this fine arteriolar tracery, as the cause of hæmorrhage and exudates can seldom be done with confidence, and a close relation between the two continues to be a probability.

Cerebral Derangement. Evidence of cerebral arterial disease was present in each of the 4 patients, appearing in the form of a stroke with severe residual hemiplegia in one, a small stroke with paralysis of one leg lasting only a day in another, a state of confusion and violent cerebral agitation 
TABLE I

Summary of Clinical Features of Four Patients with Diffuse Arteriopathy

\begin{tabular}{|c|c|c|c|c|c|c|c|c|c|}
\hline \multirow{3}{*}{$\begin{array}{l}\text { Case } \\
\text { No. }\end{array}$} & \multirow{3}{*}{ Age } & \multirow{3}{*}{$\begin{array}{c}\text { First } \\
\text { symptom }\end{array}$} & \multicolumn{6}{|c|}{ Affected arteries and their effects } & \multirow{3}{*}{$\begin{array}{l}\text { Subsequent } \\
\text { progress }\end{array}$} \\
\hline & & & \multirow[b]{2}{*}{ Cerebral } & \multirow[b]{2}{*}{ Renal } & \multirow[b]{2}{*}{ Retinal } & \multirow[b]{2}{*}{ Coronary } & \multicolumn{2}{|c|}{ Peripheral } & \\
\hline & & & & & & & Brachial & $\begin{array}{l}\text { Inter- } \\
\text { mittent } \\
\text { claudi- } \\
\text { cation }\end{array}$ & \\
\hline 1 & 52 & $\begin{array}{c}\text { Cardiac } \\
\text { asthma }\end{array}$ & $\begin{array}{c}\text { Transient } \\
\text { mono- } \\
\text { plegia }\end{array}$ & $\begin{array}{l}\text { Hyper- } \\
\text { tension; } \\
\text { albumi- } \\
\text { nuria; } \\
\text { hæmaturia; } \\
\text { high blood } \\
\text { urea }\end{array}$ & $\begin{array}{l}\text { Contracted } \\
\text { arterioles; } \\
\text { Hæmor- } \\
\text { rhage; } \\
\text { exudate }\end{array}$ & $\begin{array}{l}\text { Cardiac } \\
\text { infarction } \\
\text { (initially } \\
\text { painless) }\end{array}$ & Contracted & Absent & $\begin{array}{l}\text { Death from } \\
\text { heart } \\
\text { failure and } \\
\text { uræmia }\end{array}$ \\
\hline 2 & 57 & $\begin{array}{l}\text { Cardiac } \\
\text { pain }\end{array}$ & $\begin{array}{l}\text { Periodic } \\
\text { mental } \\
\text { con- } \\
\text { fusion }\end{array}$ & $\begin{array}{l}\text { Albumi- } \\
\text { nuria; } \\
\text { ultimate } \\
\text { hyper- } \\
\text { tension; } \\
\text { raised } \\
\text { blood urea }\end{array}$ & $\begin{array}{l}\text { One-sided } \\
\text { dimness of } \\
\text { vision; } \\
\text { contracted } \\
\text { arterioles; } \\
\text { hæmor- } \\
\text { rhage; } \\
\text { exudate }\end{array}$ & $\begin{array}{l}\text { Cardiac } \\
\text { infarction } \\
\text { (painful) }\end{array}$ & Contracted & Absent & $\begin{array}{l}\text { Death from } \\
\text { heart } \\
\text { failure }\end{array}$ \\
\hline 3 & 55 & Stroke & $\begin{array}{c}\text { Hemi- } \\
\text { plegia }\end{array}$ & $\begin{array}{l}\text { Ultimate } \\
\text { hyper- } \\
\text { tension }\end{array}$ & $\begin{array}{l}\text { Contracted } \\
\text { arterioles; } \\
\text { hæmor- } \\
\text { rhage; } \\
\text { exudate }\end{array}$ & $\begin{array}{l}\text { Cardiac } \\
\text { infarction } \\
\text { (painless) }\end{array}$ & Thickened & Absent & $\begin{array}{l}\text { Severe } \\
\text { heart } \\
\text { failure }\end{array}$ \\
\hline 4 & 48 & $\begin{array}{l}\text { Dimness } \\
\text { of vision }\end{array}$ & $\begin{array}{l}\text { Encepha- } \\
\text { lopathy; } \\
\text { periodic } \\
\text { amnesia }\end{array}$ & $\begin{array}{l}\text { Albumi- } \\
\text { nuria; } \\
\text { paroxysmal } \\
\text { hyper- } \\
\text { tension }\end{array}$ & $\begin{array}{l}\text { One-sided } \\
\text { dimness of } \\
\text { vision; } \\
\text { contracted } \\
\text { arterioles; } \\
\text { hæmor- } \\
\text { rhage; } \\
\text { exudate }\end{array}$ & $\begin{array}{l}\text { Cardiac } \\
\text { infarction } \\
\text { (painless) }\end{array}$ & Contracted & Absent & $\begin{array}{l}\text { Relatively } \\
\text { well }\end{array}$ \\
\hline
\end{tabular}

of several days' duration in the third, and as episodes of disturbing encephalopathy with amnesia in the fourth patient.

In the 2 patients with stroke, the blood pressure was $185 / 110 \mathrm{~mm} . \mathrm{Hg}$, with slight signs of left ventricular hypertrophy in the electrocardiogram in one, and with greater changes in the other whose blood pressure was $170 / 110 \mathrm{~mm}$. $\mathrm{Hg}$. In the 2 patients exhibiting transient cerebral disturbance, the blood pressure fluctuated between normal and higher values, but its level was unrelated to the cerebral episodes: the electrocardiogram in each showed early left ventricular hypertrophy.

Winter et al. (1958), investigating the degree of atherosclerosis in cerebral and coronary arteries in women, found that a wide degree of variability often existed between the severity of atherosclerosis in these arteries in any one case. Although they stated that after the fourth decade, patients with hypertension develop cerebral atherosclerosis earlier and to a more severe degree than do those whose hearts show no evidence of long-standing hypertension, their sample of seven patients in the seventh decade did not support this view.

In a series of 100 patients with systemic hypertension whose mean age was 57 years and mean blood pressure $230 / 130 \mathrm{~mm}$. $\mathrm{Hg}$, a stroke had taken place in 11, while in another series of 61 patients whose mean age was 61 years and mean blood pressure was $210 / 125 \mathrm{~mm}$. $\mathrm{Hg}$, and in whom cardiac infarction was also present, the incidence of a stroke was the same, namely 6 instances.

Peripheral Arterial Effects. In one of the four patients described here the brachial artery was 
thickened but not contracted, while in the remaining three it was contracted and whipcord-like at a time when the blood pressure was not significantly raised, although the electrocardiogram showed early left ventricular preponderance. This whipcord-like texture of the brachial and radial arteries is a common feature of systemic hypertension. Turnbull (1915) pointed out that the artery feels hardest when it is smallest, providing evidence of physiological activity rather than a degenerative process. In this form of arteriosclerosis the resistance to vascular expansion was increased.

The symptom of intermittent claudication was absent in all four patients, but the abdominal aorta and its terminal branches were not examined radiologically, nor was pulsation in the lower limb arteries tested instrumentally. McDonald (1953) found 4 patients with intermittent claudication among 50 with cardiac pain, and 23 patients with cardiac pain among 79 with intermittent claudication. In the present series, among 1100 patients with cardiac infarction, there were only 16 (13 men and 3 women) with intermittent claudication, whereas cardiac infarction was present in 16 of the 32 patients with intermittent claudication. In 2 instances of claudication, 1 with and 1 without cardiac infarction, systemic hypertension was also present.

Systemic Hypertension. In two of the patients (Cases 2 and 4), the blood pressure was natural when it was first recorded, namely $135 / 100$ and $140 / 100 \mathrm{~mm}$. $\mathrm{Hg}$ respectively at a time when the cardiogram showed left ventricular preponderance without left ventricular excitation; this latter change became added in Case 2 when the blood pressure had reached 180/130 and increased when it had reached $220 / 150 \mathrm{~mm}$. Hg. In Case 4, such left ventricular excitation remained absent when the blood pressure showed temporary rises to $230 / 145 \mathrm{~mm}$. $\mathrm{Hg}$. These two emphasize that ST-T changes in leads I and CR7 appear earlier as evidence of left ventricular hypertrophy than do changes representing left ventricular excitation (Evans, 1962).

In the other two patients (Cases 1 and 3) the blood pressure when they were first examined was $185 / 110$ and $170 / 110 \mathrm{~mm}$. $\mathrm{Hg}$ respectively, when the electrocardiogram showed left ventricular preponderance which included left ventricular excitation. Case 1 developed left ventricular failure when the blood pressure was $160 / 120 \mathrm{~mm}$. though later it reached $240 / 170 \mathrm{~mm}$. $\mathrm{Hg}$. In Case 2 the blood pressure was 180/130 when heart failure set in, and thereafter it increased to $220 / 150 \mathrm{~mm}$. Hg. In Case 3 a blood pressure of $210 / 120 \mathrm{~mm}$. $\mathrm{Hg}$ coincided with the onset of heart failure, and later it rose to $220 / 150 \mathrm{~mm}$. $\mathrm{Hg}$.

When 100 consecutive patients with systemic hypertension, having a mean blood pressure of $230 / 130 \mathrm{~mm} . \mathrm{Hg}$, and uncomplicated by either cardiac infarction or heart failure and in whom the electrocardiogram showed evidence of frank left ventricular hypertrophy were assembled for special examination, 30 were symptomless and 47 had functional complaints like tiredness, giddiness, or headache. In only 23 were there material symptoms having their source in arterial disease. Thus, 11 had a stroke, 7 complained of dimness of vision, 3 had hæmaturia, 1 had hæmoptysis, and 1 epistaxis. In only 3 of these 23 patients did more than two material symptoms ultimately exist side by side.

Cardiac Infarction. The electrocardiograms (Fig. 1 to 4) confirmed the presence of cardiac infarction in each of the four patients. In two the condition was painless while the other two were subject to cardiac pain which in one preceded, and in the other succeeded, the cardiographic diagnosis.

\section{Association of Coronary Arterial Disease and Systemic Hypertension}

Most writers have held that hypertension is a common antecedent of coronary occlusion from atherosclerosis, and have consequently regarded it as a cause. In order to avoid fallacious deductions in regard to the relation that may exist between these two conditions, it is necessary to be aware of certain circumstances that, if ignored, will lead to such erroneous conclusions.

Age Distribution of the Two Conditions. Attention has already been directed to the common incidence of the two conditions in comparable age-groups in the two sexes. Thus, when the respective age incidence was examined in 974 patients with cardiac infarction and in 300 with systemic 
hypertension, assembled over the same period of time, it was found that both conditions tended to be more frequent in the sixth decade in men, and in the seventh decade in women (Table II). Sigler (1955) found the same tendency, so that in his male patients, coronary occlusion began to appear earlier in life, and its incidence rose progressively, reaching a fastigium between 50 and 59 years. The same was true of women, but here the fastigium was reached between 60 and 69 years. Although the incidence of hypertension likewise increased with age, such increase did not correspond strictly to the increase in coronary occlusion. His figures allowed him to conclude that hypertension bore no causal relation to coronary occlusion.

Cardiac Infarction in Systemic Hypertension and in Hypertonia. A disunity among authors (Clawson, 1939; Goldstein et al., 1956; Evelyn, 1947) concerning the exact definition of systemic hypertension has meant the acceptance into their series of cases that had varying levels of blood pressure on which they have based their opinions concerning the influence of hypertension in the initiation of coronary arterial disease.

Thus, Master, Dack, and Jaffe (1939), using a systolic pressure of $150 \mathrm{~mm}$. $\mathrm{Hg}$ and/or a diastolic pressure of $90 \mathrm{~mm}$. $\mathrm{Hg}$ as a definition of hypertension, found hypertension in more than half the men and in four-fifths of the women in their series of 500 cases of coronary occlusion. This led them to conclude that hypertension was an ætiological factor in coronary occlusion. In 1950, however, Master, Dublin, and Marks recognized that a systolic blood pressure of 160 to 190 and a diastolic blood pressure of 100 to $110 \mathrm{~mm}$. $\mathrm{Hg}$ were not uncommonly observed in subjects over 50 years of age who appeared to be healthy. This caused Master (1953) to revise his previous

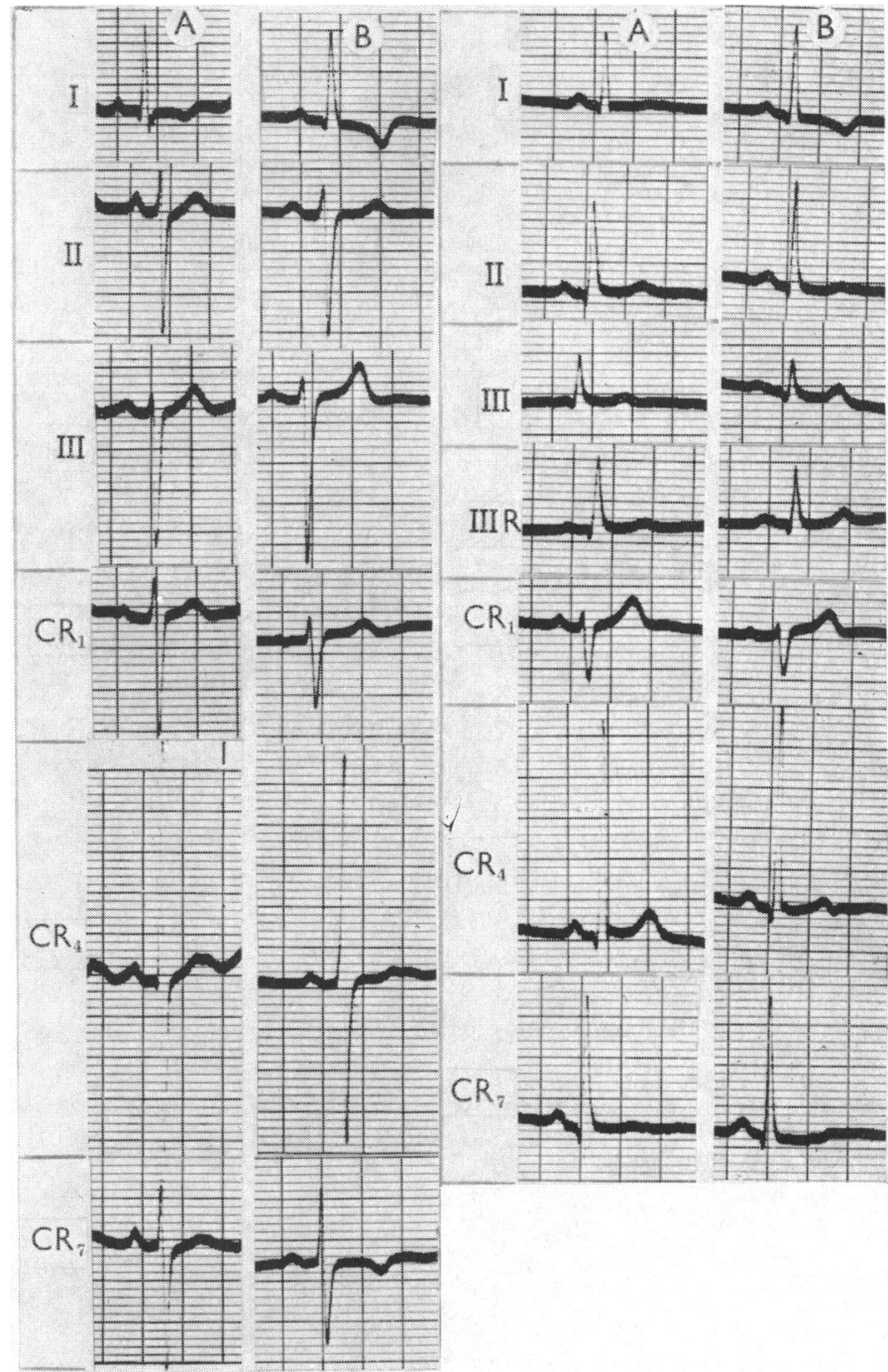

Fig. 3.-Cardiac infarction told by the inverted $T$ wave in lead I and the bifid T in CR4 in the tracing (A), together with more obvious changes in (B) recorded two years later, when a deep S wave in leads II and III while absent in lead I had been added as a further significant change. Depression and/or inversion of $T$ waves in both (A) and (B), along with left ventricular excitation, giving values of 83 and $77 \mathrm{~mm}$. respectively for $\mathrm{R} 1 /$ RS4/R7, provided evidence of left ventricular hypertrophy (from Case 3).
Fig. 4.-Cardiac infarction told by changes in the $T$ wave in leads I and CR7 in (A), and in I and CR4 in (B) recorded five years later. The S-T depression in lead CR7 and $\mathrm{I}$ in (B) from left ventricular hypertrophy, confirms that part of the changes in (A) was due to the same cause. In neither record was there left ventricular excitation (from Case 4). 
TABLE II

Age Incidence in 974 Patients with Cardiac Infarction, and in 300 with Systemic Hypertension, Assembled Consecutively in Consulting Practice

\begin{tabular}{c|c|c|c|c}
\hline \multirow{2}{*}{ Age-groups } & \multicolumn{2}{|c|}{ Men } & \multicolumn{2}{c}{ Women } \\
\cline { 2 - 5 } & $\begin{array}{c}\text { Cardiac } \\
\text { infarction }\end{array}$ & $\begin{array}{c}\text { Systemic } \\
\text { hypertension }\end{array}$ & $\begin{array}{c}\text { Cardiac } \\
\text { infarction }\end{array}$ & $\begin{array}{c}\text { Systemic } \\
\text { hypertension }\end{array}$ \\
\hline $30-39$ & 28 & 6 & 2 & 2 \\
$40-49$ & 145 & 26 & 25 & 11 \\
$50-59$ & 338 & 73 & 53 & 23 \\
$60-69$ & 205 & 71 & 65 & 19 \\
70 and older & 72 & 29 & 41 & 95 \\
Total & 788 & 205 & 186 & \\
\hline
\end{tabular}

views on the relation between hypertension and coronary arterial disease. Finding that 70 per cent of men had a normal blood pressure before the onset of coronary occlusion, he concluded that hypertension was not the all important factor in its causation in men. On the other hand he maintained that as 71 per cent of women showed hypertension before sustaining coronary occlusion, it was a significant ætiological factor in women. Here again, a dependence on blood pressure figures alone in the diagnosis of hypertension introduces an error into the analysis, because it has been shown (Evans, 1962) that the innocent state of hypertonia in which the blood pressure value is raised to impressive heights is much commoner in women than in men. Adopting the older definition of hypertension as one showing a systolic pressure above 150 and a diastolic pressure above $90 \mathrm{~mm}$. $\mathrm{Hg}$, Davis and Klainer (1940) also concluded that hypertension increased the incidence of coronary atherosclerosis, and proportionately in both sexes. Turnbull (1915), basing his views on an extensive experience in the examination of the arterial system at necropsy, pointed out that in cases showing very high blood pressure during life and great cardiovascular hypertrophy, there might be little atheroma, while severe atheroma was often found in instances of atrophy of the heart and of the media of arteries. He stated that atheroma was more intimately related to the age of the patient than to his blood pressure.

In each of 300 patients with systemic hypertension the electrocardiogram showed left ventricular preponderance as instanced by depression of the S-T segment in leads I and CR7, providing evidence of left ventricular hypertrophy.

In contrast with this series there were assembled during the same period 114 cases of hypertonia, 44 men and 70 women, where the blood pressure in each instance was $200 / 110 \mathrm{~mm}$. Hg or higher, and where the mean value for the whole group was $220 / 115 \mathrm{~mm}$. Hg. The electrocardiogram was normal in every case, showing neither S-T depression nor left ventricular excitation. They were regarded as healthy subjects with a physiological rise in the blood pressure at the time of the examination (Evans, 1957, 1962).

The incidence of cardiac infarction was the same for both groups, namely 41 per cent for the hypertensive group and 42 per cent for the hypertonic group, with a preponderance showing among the men in the latter group, namely 52 per cent against 44 per cent (Table III).

Hypertension in Cardiac Infarction. A clinical estimate of the incidence of cardiac infarction in hypertension sometimes meets with the difficulty of interpreting the electrocardiogram, when left ventricular preponderance from hypertension is associated with infarction residing at the lateral border of the left ventricle. The criteria adopted here for this dual diagnosis included a history of cardiac pain, electrocardiographic evidence of infarction in some portion of the left ventricle other than its lateral aspect, a changing cardiographic pattern over a short period of time, greater depression of the S-T segment in lead CR7 than in I, and a depression of the S-T in lead IIIR.

Stress, however, is laid on the need to recognize painless cardiac infarction in any assay which has as its object the discovery of the incidence of infarction either alone or in association with other examples of arterial disease like systemic hypertension. Thus, among 1100 cases with normal 
TABLE III

Incidence of Cardiac Infarction in 300 Patients with Systemic Hypertension, and in 114 Healthy Subjects WITH HYPERTONIA

\begin{tabular}{|c|c|c|c|c|}
\hline \multirow{2}{*}{ Clinical state } & \multicolumn{2}{|c|}{ Men } & \multicolumn{2}{|c|}{ Women } \\
\hline & Total & $\begin{array}{l}\text { Cardiac } \\
\text { infarction }\end{array}$ & Total & $\begin{array}{c}\text { Cardiac } \\
\text { infarction }\end{array}$ \\
\hline Systemic hypertension (300) & 205 & 90 & 95 & 35 \\
\hline Hypertonia (114) .. & $\begin{array}{c}(68 \%) \\
44 \\
(38 \%)\end{array}$ & $\begin{array}{l}(44 \%) \\
23 \\
(52 \%)\end{array}$ & $\begin{array}{c}(32 \%) \\
70 \\
(62 \%)\end{array}$ & $\begin{array}{c}(37 \%) \\
25) \\
(35 \%)\end{array}$ \\
\hline
\end{tabular}

blood pressure cardiac infarction the myocardial injury was accompanied by cardiac pain in 1007 , or 91 per cent, and was painless in 9 per cent. Among 125 patients in whom systemic hypertension was present with cardiac infarction, painless cardiac infarction was a much commoner event $(29 \%)$, especially in women (Table IV).

TABLE IV

Relative Incidence of Painful and Painless Cardiac Infarction, when Occurring Alone and in Association WITH SYSTEMIC HYPERTENSION

\begin{tabular}{|c|c|c|c|c|c|c|}
\hline \multirow{3}{*}{ Clinical state } & \multicolumn{3}{|c|}{ Men } & \multicolumn{3}{|c|}{ Women } \\
\hline & \multirow{2}{*}{ Total } & \multicolumn{2}{|c|}{ Cardiac infarction } & \multirow{2}{*}{ Total } & \multicolumn{2}{|c|}{ Cardiac infarction } \\
\hline & & Painful & Painless & & Painful & Painless \\
\hline 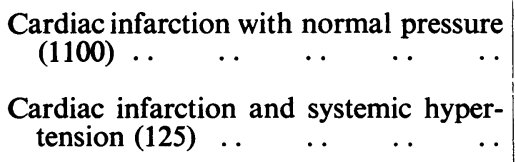 & $\begin{array}{c}870 \\
(79 \%) \\
90 \\
(72 \%)\end{array}$ & $\begin{array}{c}809 \\
(93 \%) \\
69 \\
(76 \%)\end{array}$ & $\begin{array}{c}61 \\
(7 \%) \\
21 \\
(24 \%)\end{array}$ & $\begin{array}{l}230 \\
(21 \%) \\
35 \\
(28 \%)\end{array}$ & $\begin{array}{c}198 \\
(86 \%) \\
20 \\
(57 \%)\end{array}$ & $\begin{array}{c}32 \\
(14 \%) \\
15 \%) \\
(43 \%)\end{array}$ \\
\hline
\end{tabular}

Among 1225 consecutive patients with cardiac infarction, hypertension was an added condition in only 125 instances, an incidence of only 10 per cent, so that although they were of comparable ages to the 300 patients with systemic hypertension ( 175 with lone hypertension and 125 with associated cardiac infarction), in as many as 1100 , or 90 per cent, hypertension had not provided a cause for coronary arterial disease that had given rise to cardiac infarction.

Localized Hypertension. When the confined pulmonary circulation is subjected to a raised blood pressure, atherosclerosis develops in the main pulmonary artery. Thus, Turnbull (1915) emphasized the common occurrence of intimal hypertrophy in focal high blood pressure as seen in the pulmonary arteries in cases of resistance to the flow of blood into the left heart as in mitral stenosis. Again, Heath et al. (1960) from their examination of 21 cases of pulmonary stenosis, 22 with pulmonary hypertension from birth, and 22 cases of congenital or acquired heart disease in some of which pulmonary hypertension was acquired, concluded that pulmonary hypertension and high pulmonary blood flow, contributed to the ætiology of pulmonary atheroma.

In coarctation of the aorta where the early portion of the aorta is subject to a high blood pressure, the commonest change is a decrease in its thickness with a varying amount of necrosis or hyaline degeneration along with some degree of atheromatosis (Reifenstein, Levine, and Gross, 1947). The raised tension is not so sustained here as in the case of pulmonary hypertension because of an efficient collateral circulation.

As pointed out by Burch and Phillips (1960) hypertension should not be regarded as the most important localizing factor for atherogenesis in all segments of the circulation, for the coronary 
arterial system may present a completely different picture from that existing in the aorta and other large vessels.

Specificity of Diffuse Arteriopathy. Among the different conditions that affect the separate arterial systems, the most commonly associated are hypertension and cardiac infarction or cardiac infarction and intermittent claudication, and it has been shown already that such association is less related to cause and effect, than to their natural incidence in the same age-groups (Table V).

TABLE V

Nature and Localization of Vascular Disease in 1354 Patients Examined Consecutively

Specified vascular derangement

\begin{tabular}{|c|c|c|c|c|c|c|c|}
\hline \multicolumn{2}{|c|}{ Lone lesions } & \multicolumn{2}{|l|}{ Dual lesions } & \multicolumn{2}{|l|}{ Triple lesions } & \multicolumn{2}{|c|}{ Diffuse arteriopathy } \\
\hline Nature & No. & Nature & No. & Nature & No. & Nature & No. \\
\hline $\begin{array}{l}\text { Cardiac infarction } \\
\text { Hypertension } \\
\text { Claudication }\end{array}$ & $\begin{array}{r}1017 \\
149 \\
16\end{array}$ & $\begin{array}{l}\text { Cardiac infarction } \\
\text { and hypertension } \\
\text { Cardiac infarction } \\
\text { and claudication } \\
\text { Hypertension and } \\
\text { cerebral infarction } \\
\text { Hypertension and } \\
\text { retinal infarction } \\
\text { Hypertension and } \\
\text { hæmaturia } \\
\text { Hypertension and } \\
\text { epistaxis } \\
\text { Hypertension and } \\
\text { hæmoptysis } \\
\text { Hypertension and } \\
\text { claudication }\end{array}$ & $\begin{array}{r}125 \\
16 \\
11 \\
7 \\
3 \\
1 \\
1 \\
1\end{array}$ & $\begin{array}{l}\text { Hypertension, } \\
\text { cerebral, and } \\
\text { retinal infarction } \\
\text { Hypertension, } \\
\text { cerebral infarction, } \\
\text { and claudication }\end{array}$ & $\begin{array}{l}2 \\
1\end{array}$ & $\begin{array}{l}\text { Cardiac infarction, } \\
\text { hypertension, } \\
\text { retinal infarction, } \\
\text { and cerebral } \\
\text { arterial } \\
\text { derangement }\end{array}$ & 4 \\
\hline Total & 1182 & Total & 165 & Total & 3 & Total & 4 \\
\hline
\end{tabular}

When either cerebral or retinal infarction had taken place in patients with hypertension where the blood pressure was known to have been both high and sustained through many years, the events were regarded as natural complications of the raised pressure and not necessarily as primary effects of localized disease of the respective arterial units. The four patients with diffuse arteriopathy, however, differed from these in that cerebral, retinal, coronary, and peripheral arterial derangement was present when the blood pressure was natural in two and was only slightly raised in the other two.

A common pathology does not underlie these several arterial lesions, so that although atherosclerosis accounts for the coronary, retinal, and cerebral arterial faults, contraction, especially of the peripheral arteries, is allied to the developing hypertension, while the hypertension itself springs from intimal proliferation of the lesser renal arteries, which in turn initiates renal ischæmia, the rarer event of atheromatous stenosis of a main renal artery having been excluded.

The simultaneous appearance of occlusive effects in so many arterial domains in these four patients suggests for diffuse arteriopathy the presence of an arterial weakness, structural in the case of the renal vessels (Evans, 1960), and in the form of an inherent tendency to develop atheromatosis in other arteries.

\section{SUMMARY}

Diffuse arteriopathy is the term proposed for a rare clinical entity in which a fortuitous examination or one conducted following the event of a single symptom, reveals generalized arterial disease 
involving several arterial territories. Its clinical features are described in relation to four patients presenting the disease.

The four patients were men and in the sixth decade of life. In one a fortuitous medical examination and in another a casual examination on account of tiredness uncovered the condition, while cardiac pain and a stroke respectively were symptoms that compelled the remaining two to seek medical advice. In each the electrocardiogram showed evidence of cardiac infarction, which was painful in one, ultimately painful in a second, and remaining painless in the other two. Retinoscopy found contracted arterioles, hæmorrhages, and exudates in each patient. Symptoms of cerebral arterial derangement appeared in all four at a time when the blood pressure was normal in two and only slightly raised in two. Similarly, an unusually thickened brachial artery, which in three was contracted as well, presented before a substantial rise in the blood pressure. Although the initial blood pressure readings in the four patients were $185 / 100,135 / 100,170 / 110$, and 140/100 $\mathrm{mm} . \mathrm{Hg}$ respectively when they were first examined, changes in the electrocardiogram due to left ventricular preponderance were present in each, additional to left ventricular excitation in two, a sign that developed later in a third case. Subsequent blood pressure readings in the four patients were $160 / 120,180 / 130,210 / 120$, and $230 / 145 \mathrm{~mm}$. $\mathrm{Hg}$, and these were obtained at a time when left ventricular failure had set in in the first three, although later the blood pressure in the face of severe heart failure rose in these three to $240 / 170,220 / 150$, and $220 / 150 \mathrm{~mm}$. $\mathrm{Hg}$ respectively.

These patients came under observation during a period when 1354 consecutive cases were found with disease affecting one or more arterial systems. Thus, a single arterial unit only was involved in 1182 , two units in 165 , and three units in only 3 patients.

The association with hypertension of arterial disease in other places such as cerebral and retinal infarction resulted in most patients mainly as a complication of severe and long-maintained high blood pressure, but such was not the mechanism in the four patients with diffuse arteriopathy reported here, for these arterial faults took place before the blood pressure had risen significantly.

Cardiac infarction and hypertension are the conditions that appear most frequently side by side, and because of this, the view held by many that hypertension causes coronary atherosclerosis was specially examined. Evidence was assembled that opposes this view, and the two conditions were shown to be independent lesions appearing fortuitously in association in a common age-group. The chief reason for the contrary belief arises from a failure to differentiate between hypertension and the innocent state of hypertonia.

This widespread disease of the arterial system in which signs appearing insidiously arise from simultaneous involvement of the coronary, cerebral, retinal, renal, and sometimes the peripheral circulation, invites the postulation that a single mechanism underlies it, namely an inherent weakness in the arterial wall. Such weakness in the renal arteries takes the form of deficiency of the medial coat which breeds occlusive intimal proliferation causing renal ischæmia which in turn gives rise to systemic hypertension. In the other arterial units, the weakness takes the form of a predisposition to occlusive atherosclerosis causing ischæmia of the affected viscera or limbs.

\section{REFERENCES}

Burch, G. E., and Phillips, J. H. (1960). Hypertension and arteriosclerosis. Amer. Heart J., $60,163$.

Clawson, B. J. (1939). Coronary sclerosis. Amer. Heart J., 17, 387.

Davis, D., and Klainer, M. J. (1940). The incidence of coronary atherosclerosis in cases of essential hypertension. Amer. Heart J., 19, 185.

Evans, W. (1957). Hypertonia or uneventful high blood pressure. Lancet, 2, 53.

- (1960). The ætiology of systemic hypertension. Brit. Heart J., 22, 17.

(1962). The electrocardiogram in the diagnosis of systemic hypertension. Brit. Heart J., $24,469$.

Evelyn, K. A. (1947). The state of the arterioles in essential hypertension. Amer.J. med. Sci., $214,312$.

Goldstein, F., Jenson, W. K., Waldron, J. M., and Duncan, G. G. (1956). The relationship between hypertension and coronary occlusion. Ann. intern. Med., 44, 446.

Greear, J. N. (1940). The eye in hypertensive cardiovascular disease. Trans. Amer. ophthal. Soc., $38,397$.

Heath, D., Wood, E. H., DuShane, J. W., and Edwards, J. E. (1960). The relation of age and blood pressure to atheroma in the pulmonary arteries and thoracic aorta in congenital heart disease. Lab. Invest., 9, 259.

McDonald, L. (1953). Ischæmic heart disease and peripheral occlusive arterial disease. Brit. Heart J., $15,101$. 
Manlove, F. R. (1946). Retinal and choroidal arterioles in malignant hypertension. Arch. intern. Med., 78, 419.

Master, A. M. (1953). Hypertension and coronary occlusion. Circulation, 8, 170.

- , Dack, S., and Jaffe, H. L. (1939). Age, sex and hypertension in myocardial infarction due to coronary occlusion. Arch. intern. Med., 64, 767.

- - Dublin, L. I., and Marks, H. H. (1950). The normal blood pressure range and its clinical implications. J. Amer. med. Ass., 143, 1464.

Reifenstein, G. H., Levine, S. A., and Gross, R. E. (1947). Coarctation of the aorta. Amer. Heart J., $33,146$.

Sigler, L. H. (1955). The role of hypertension in the ætiology and prognosis of coronary occlusion. Ann. intern. Med., 42, 369.

Turnbull, H. M. (1915). Alterations in arterial structure and their relation to syphilis. Quart. J. Med., 8, 201.

Winter, M. D., Sayre, G. P., Millikan, C. H., and Barker, N. W. (1958). Relationship of degree of atherosclerosis of internal carotid system in the brain of women to age and coronary atherosclerosis. Circulation, 18, 7. 